\title{
Perbedaan Kinerja Keuangan dan Kinerja Pasar Perusahaan Indeks Sri-Kehati dengan Perusahaan Non Indeks Sri-Kehati Periode 2015 - 2017
}

\author{
Esther Kusumawati ${ }^{1}$ \\ Yusni Warastuti ${ }^{*}$ \\ ${ }^{1,2}$ Universitas Katolik Soegijapranata \\ *Corresponding author email: yusni@unika.ac.id
}

\begin{abstract}
The increasingly fierce level of competition has prompted companies to seek new ways to attract capital market investors. Market players are increasingly aware of the impact of company activities on the environment and sustainability reporting. Capital market authorities are also increasingly concerned about investors' attention to environmental damage caused by uncontrolled exploitation of natural resources. In cooperation with the Biodiversity Foundation (KEHATI), Indonesia Stock Exchange formed a new index called the SRI-KEHATI in 2008. Firms included in the SRI-KEHATI index category are firms that pay serious attention to environmental, social and good corporate governance issues. This study examines the differences in financial performance and market performance of companies that are included in the SRI-KEHATI index group and those of non-SRI-KEHATI index companies. Financial performance is measured by the ratio of net profit margin, return on assets, and return on equity. Meanwhile, market performance is measured by the price earnings ratio. The results show that the ratios of NPM, ROA, ROE, and PER of firms included in SRIKEHATI index are higher than non-SRI-KEHATI index.
\end{abstract}

Keywords: SRI-KEHATI Index, sustainability reporting, financial performance, market performances

\begin{abstract}
Abstrak
Tingkat kompetisi yang semakin ketat telah mendorong perusahaan untuk mencari cara-cara baru dalam menarik minat investor pasar modal. Pelaku pasar semakin sadar tentang dampak aktivitas perusahaan terhadap lingkungan dan sustainability reporting. Badan otoritas pasar modal juga semakin perduli tentang perhatian investor terhadap kerusakan lingkungan yang diakibatkan eksploitasi sumber daya alam yang tidak terkendali. Bekerjasama dengan Yayasan Keanekaragaman Hayati (KEHATI), pada tahun 2008 Bursa Efek Indonesia. membentuk suatu indeks baru yang diberi nama indeks SRI-KEHATI. Perusahaan-perusahaan yang masuk dalam kategori indeks SRI-KEHATI adalah perusahaan yang memberi perhatian serius terhadap masalah lingkungan, sosial, dan tata kelola perusahaan yang baik (good corporate governance). Penelitian ini menguji perbedaan kinerja keuangan dan kinerja pasar perusahaan yang masuk kedalam kelompok indeks SRI-KEHATI dengan perusahaan non indeks SRI-KEHATI. Kinerja keuangan diukur dengan rasio net profit margin, return on asset, dan return on equity. Sedangkan kinerja pasar diukur dengan price earnings ratio. Hasil penelitian menunjukkan bahwa rasio NPM, ROA, ROE, dan PER perusahaan yang termasuk dalam kelompok indeks SRI-KEHATI dan lebih tinggi daripada kelompok perusahaan non indeks SRI-KEHATI.
\end{abstract}

Kata Kunci: indeks SRI-KEHATI, sustainability reporting, kinerja keuangan, kinerja pasar. 


\section{PENDAhuluan}

Sesuai dengan Keputusan Direksi PT Bursa Efek Jakarta Nomor: Kep-306/BEJ/07-2004 perusahaan-perusahaan yang tergabung dalam Bursa Efek Indonesia diwajibkan untuk menerbitkan laporan keuangan, baik laporan keuangan interim maupun laporan keuangan tahunan. Demi menyajikan informasi-informasi yang relevan dan sesuai dengan peraturan peraturan yang ada, pada tahun 2008 Bursa Efek Indonesia bekerjasama dengan Yayasan Keanekaragaman Hayati (KEHATI) membentuk suatu indeks baru yang diberi nama indeks SRI-KEHATI. Perusahaan-perusahaan yang masuk dalam kategori indeks SRI-KEHATI adalah perusahaan yang mendukung terciptanya keberlanjutan (sustainability) dengan cara peduli terhadap lingkungan, sosial, dan tata kelola perusahaan yang baik (good corporate governance), yang sesuai dengan peraturan yang ditetapkan oleh pemerintah tentang tanggung jawab sosial perusahaan (Jogiyanto, 2016:176).

Penilaian terhadap perusahaan yang tergabung dalam Indeks SRI-KEHATI difokuskan dalam tiga aspek yaitu bisnis inti, finansial dan fundamental. Seleksi aspek bisnis inti mencakup beberapa aspek yaitu perusahaan tidak bergerak di bidang yang dianggap negatif seperti pertambangan batubara, pestisida, alkohol, tembakau, senjata, perjudian, nuklir, pornografi, dan rekayasa genetika. Dari aspek finansial, emiten harus memiliki kapitalisasi pasar dan total aset yang lebih dari 1 triliun, nilai Price Earning Ratio (PER) yang dimiliki perusahaan bernilai positif, dan jumlah saham yang beredar secara publik lebih dari $10 \%$. Untuk aspek fundamental, emiten dinilai berdasarkan faktor fundamental yaitu: tata kelola perusahaan, lingkungan, partisipasi masyarakat, perilaku bisnis, hak asasi manusia, dan sumber daya manusia. Dengan kata lain perusahaan dalam indeks SRI-KEHATI dikategorikan sebagai perusahaan besar yang hijau.

Penilaian investor terhadap perusahaan umumnya dilakukan dengan dengan melihat angka-angka dalam laporan keuangan yang dirilis ke publik. Angka-angka tersebut diolah lebih lanjut untuk menghasilkan berbagai macam rasio diantaranya rasio likuiditas, rasio profitabilitas, rasio solvabilitas (leverage) dan rasio aktivitas. Rasio-rasio tersebut mencerminkan keadaan perusahaan yang sesungguhnya. Selain kinerja keuangan, investor juga dapat menilai dari sisi kinerja pasar perusahaan. Kinerja pasar mencerminkan kepercayaan investor terhadap prospek perusahaan ke depan. Kinerja pasar dapat tercermin dari price earning ratio dan price to book value.

Berbagai penelitian yang berfokus pada rasio-rasio keuangan telah banyak dilakukan tetapi yang berfokus pada kinerja lingkungan belum banyak. Penelitian sebelumnya yang menggunakan sampel perusahaan dalam kelompok indeks SRI-KEHATI di antaranya Kurniasari dan Warastuti (2015) yang meneliti tentang pengaruh CSR dan profitablitas terhadap nilai perusahaan. Hasil penelitian menunjukkan bahwa profitabilitas berpengaruh terhadap nilai perusahaan, sedangkan CSR tidak berpengaruh secara signifikan.

Berbeda dengan penelitian sebelumnya yang lebih berfokus pada hubungan antara CSR dan kinerja keuangan, penelitian ini lebih menekankan pada perbedaan kinerja keuangan dan kinerja pasar diantara perusahaan-perusahaan yang masuk daam indeks SRI-KEHATI dan perusahaan-perusahaan yang tidak termasuk ke dalamnya. Lebih spesifik, pengujian ini mencoba memberikan bukti empiris apakah perusahaan yang masuk dalam kelompok indeks SRI-KEHATI memiliki kinerja yang lebih baik dibandingkan perusahaan yang tidak masuk dalam kategori ini. 


\section{TINJAUAN LITERATUR DAN PERUMUSAN HIPOTESIS}

\section{Kinerja Keuangan}

Kinerja perusahaan adalah gambaran performa perusahaan dalam jangka waktu tertentu. Penilaan kinerja dilakukan guna mengetahui sejauh mana performa yang dimiliki oleh perusahaan dalam mengelola segala sumber daya yang dimiliki, sehingga dapat membantu pihak manajemen dalam pengambilan keputusan (Alexander dan Destriana, 2013). Proses penilaian kinerja dapat dilakukan dari segi keuangan maupun non keuangan. Dari segi keuangan perusahaan dapat melihat dari rasio-rasio keuangan. Rasio keuangan adalah salah satu alat yang digunakan dalam menilai kinerja dan kondisi perusahaan.

\section{Rasio Profitabilitas}

Rasio profitabilitas merupakan rasio keuangan untuk mengetahui seberapa besar laba yang akan dihasilkan oleh perusahaan dari sumberdaya yang dimiliki oleh perusahaan. Rasio profitabilitas bertujuan untuk mengukur efisiensi dari perusahaan tersebut (Sutriani,2014) . Profitabilitas dapat diproksi melalui :

\section{a. Return on Asset (ROA)}

Rasio ini merupakan perbandingan antara laba bersih perusahaan dengan total asset yang dimiliki oleh perusahaan. Semakin besar nilai besarnya nilai ROA yang dimiliki perusahaan, menandakan bahwa perusahaan mampu mengelola asset yang dimiliki menjadi laba yang nantinya akan menguntungan perusahaam maupun pihak ketiga (investor). ROA dapat dirumuskan dengan (Hantono,2018) :

$$
\text { Return on asset }(\mathrm{ROA})=\frac{\text { Laba Bersih }}{\text { Total } \text { Aset }}
$$

\section{b. Return On Equity (ROE)}

Rasio mencerminkan tingkat pengembalian yang diperoleh pemilik bisnis atas modal yang telah ditanamkan. Nilai ROE positif, artinya bahwa semakin besar nilai dari ROE maka semakin baik pula kinerja dari perusahaan. ROE dapat dihitung menggunakan (Hantono, 2018)

\section{c. $\quad$ Net Profit Margin (NPM)}

$$
\text { Return on equity }(\mathrm{ROE})=\frac{\text { Laba Bersih }}{\text { Total Ekuitas }}
$$

Rasio ini merupakan ukuran prosentase laba neto yang dihasilkan perusahaan dari total penjualannya. NPM dapat dirumuskan dengan (Hantono,2018):

$$
\text { Net Profit Margin }(\mathrm{NPM})=\frac{\text { Laba Penjualan }}{\text { Penjualan }}
$$

\section{Kinerja Pasar}

Kinerja pasar adalah usaha yang dilakukan perusahaan dalam meningkatkan harga saham di pasar. Ketika harga saham perusahaan tinggi maka kinerja pasar dari perusahaan tersebut juga cenderung tinggi. Kinerja pasar dapat diukur menggunakan Price Earning Ratio (PER). PER adalah perbandingan antara harga pasar per lembar saham dengan laba per lembar saham. Jika perusahaan mempunyai tingkat pertumbuhan yang ditinggi, maka PER yang dimiliki perusahaan tersbeut juga relatif tinggi. Besar kecilnya nilai PER dapat dihitung menggunakan rumus (Halim dan Mamduh, 2009:85): 


$$
\text { Price Earning Ratio }(\mathrm{PER})=\frac{\text { Harga pasar per lembar saham }}{\text { Laba per Lembar Saham }}
$$

Laba per lembar saham atau biasa disebut EPS (earnings per share) adalah perbandingan antara laba bersih perusahaan dibagi dengan jumlah saham yang beredar di pasar. Harga pasar yang dapat digunakan untuk menghitung nilai PER adalah harga pasar terbaru atau harga pasar pada saat tutup buku atau akhir dari tahun.

\section{Indeks SRI-KEHATI}

Indeks SRI-KEHATI merupakan hasil kerjasama antara IDX dengan Yayasan KEHATI (Yayasan Keanekaragaman Hayati Indonesia) dan dirilis pada tanggal 29 Juni 2009 (Jogiyanto, 2016). Indeks SRI-KEHATI ini mengacu pada tata cara Sustainable and Responsible Investment (SRI).

Penilaian indeks saham SRI-KEHATI dilakukan melalui tiga tahap yaitu:

1. Tahap pertama, seleksi dilakukan dengan melihat bisnis inti (core business). Pada tahap ini, KEHATI melakukan seleksi untuk memastikan bahwa perusahaan yang masuk dalam kategori indeks SRI-KEHATI tidak bergerak dan memiliki usaha inti pada sembilan jenis bisnis berikut ini: pestisida, nuklir, senjata, tembakau, alkohol, pornografi, perjudian, genetically modified organism (GMO), dan pertambangan batu bara.

2. Tahap kedua, adalah seleksi pada aspek finansial yang dimiliki oleh perusahaan. Berikut adalah ketentuan dari aspek finansial perusahaan yang harus dipenuhi oleh perusahaan perusahaan dalam indeks SRI-KEHATI :

a) Perusahaan yang masuk dalam indeks SRI-KEHATI adalah perusahaan yang memiliki total asset di atas 1 (satu) triliun.

b) Perusahaan memiliki nilai Price Earning Ratio (PER) positif.

c) Perusahaan memiliki Free Float Ratio atau rasio kepemilikian saham publik di atas $10 \%$.

3. Tahap ketiga, adalah seleksi aspek fundamental perusahaan. Pada tahap ini perusahaan akan dinilai berdasarkan enam faktor utama yang mengacu pada hubungan antara perusahaan dengan lingkup sosial maupun lingkungan. Di mana keenam faktor tersebut meliputi:

a) Environmental (Lingkungan)

b) Community (Keterlibatan masyarakat)

c) Corporate Governance (Tata kelola perusahaan)

d) Human Rights (Hak Asasi Manusia (HAM))

e) Bussiness Behaviour (Perilaku bisnis)

f) Labour Practices dan decent work (Sumber daya manusia)

Pada dasarnya dalam menentukan dan memilih saham saham yang masuk dalam kriteria fundamental, yayasan KEHATI bekerja sama dengan independent data provider yaitu OWWConsulting. OWW-Consulting adalah suatau perusahaan di Kuala Lumur dimana perusahaan ini bergerak dalam bidang penelitian CSR. Ruang lingkup penelitian CSR yang dilakukan oleh OWW-Consulting meliputi wilayah Asia-Pasifik, Eropa, dan Timur Tengah. Melalui OWW-Consulting inilah Bursa Efek Indonesia dan Yayasan KEHATI menilai kierja CSR dari perusahaan perusahaan yang masuk dalam seleksi kelompok Indeks SRI-KEHATI.

Bursa Efek Indonesia dan yayasan KEHATI secara rutin memantau komponen komponen saham yang masuk dalam perhitungan indek. Review dan pergantian saham yang masuk dalam perhitungan indeks SRI-KEHATI dilakukan setiap enam bulan yaitu Mei dan 
November. Sedangkan untuk hari dasar daru indeks ini adalah 28 Desember 2008 dengan nilai indeks adalah 100 (Hartono,2016).

\section{Perumusan Hipotesis}

\section{Net Profit Margin}

Net Profit Margin atau biasa disebut dengan NPM adalah indikator yang sangat penting untuk mengukur suatu kinerja keuangan perusahaan. NPM adalah rasio yang mencerminkan keberhasilan yang diraih oleh perusahaan dan telah dikurangkan dengan biaya atau beban beban operasional perusahaan itu sendiri. Nilai dari NPM bersifat positif yang artinya semakin besar nilai NPM suatu perusahaan, maka semakin bagus pula kinerja dari perusahaan tersebut. Menurut penelitian yang dilakukan oleh Sitorus dan Mangoting (2014) menyatakan bahwa semakain besar nilai NPM suatu perusahaan maka semakin besar peluang perusahaan menghasilkan laba yang tinggi.

Peningkatan nilai NPM pada dasarnya dapat dilakukan dengan beberapa cara, yang salah satunya adalah perusahaan dapat melakukan program tanggung jawab sosial perusahaan atau yang dikenal dengan Corporate Social Responsibility atau CSR. Ketika perusahaan menjalankan program CSR secara tidak langsung perusahaan sedang meminimalkan risiko yang akan dihadapi dngan demikian perusahaan juga berupaya dalam meminimalkan biaya biaya yang dikeluarkan oleh perusahaan. Penelitian yang dilakukan Sitorus dan Mangoting (2014) juga menunjukan bahwa pengungkapan kegiatan CSR berhubungan signifikan positif dengan rasio NPM.

Perusahaan dalam indeks SRI-KEHATI adalah perusahaan yang dianggap sebagai perusahaan yang memiliki kinerja keuangan yang tinggi dan juga perusahaan yang mencerminkan keberlanjutan dengan rasa tanggung jawab sosial yang tinggi. Di mana pastinya perusahaan yang memiliki rasa tanggung jawab sosial yang tinggi akan memiliki nilai rasio NPM yang lebih tinggi dari pada perusahaan perusahaan yang kurang peduli akan kegiatan sosial perusahaan (CSR) atau bahkan belum melakukan kegiatan CSR itu sendiri. Dengan demikian hipotesis yang diajukan adalah:

\section{H1: Terdapat perbedaan net profit margin perusahaan yang masuk dalam indeks SRI- KEHATI dengan yang tidak masuk Indeks SRI-KEHATI.}

\section{Return on Asset}

Rasio return on asset mencerminkan kemampuan perusahaan dalam mengelola aset aset yang dimiliki menjadi laba perusahaan. Semakin tinggi rasio ROA yang dimiliki perusahaan maka semakin baik pula kinerja perusahaan tersebut. Perusahaan mampu mengelola aset yang dimiliki dengan efisien dan efektif sehingga laba yang dihasilkan semakin meningkat.

Mengingat bahwa perusahaan-perusahaan yang masuk dalam indeks SRI-KEHATI adalah perusahaan yang memiliki tata-kelola yang baik maka dapat diekspektasikan perusahaan-perusahaan ini memiliki laba yang lebih tinggi dari pada perusahaan non indeks SRI-KEHATI. Pernyataan tersebut didukung oleh Rosdwianti et al. (2016) yang menyatakan bahwa CSR berpengaruh terhadap kinerja rasio profitabilitas yang diukur dengan ROA. Selain itu, perusahaan yang masuk dalam indeks SRI-KEHATI adalah perusahaan yang memiliki kesadaran yang tinggi akan sosial dan lingkungan sehingga tidak mengalami masalah-masalah 
sosial dan lingkungan yang serius dalam meningkatkan kinerja keuangan. Berdasarkan paparan diatas maka hipotesis yang diajukan

\section{H2: Terdapat perbedaan return on asset perusahaan yang masuk dalam indeks SRI- KEHATI dengan yang tidak masuk Indeks SRI-KEHATI.}

\section{Return on Equity}

Return on Equity (ROE) memproksikan nilai profitabilitas suatu perusahaan. ROE merupakan tingat pengembalian yang diperoleh pemilik bisnis atas modal yang telah ditanamkan. Semakin besar nilai rasio ROE suatu perusahaan menandakan bahwa perusahaan tersebut memiliki kinerja keuangan yang baik. Dimana perusahaan mampu memgembalikan keuntungan atas modal modal yang sudah di dapatkan.

Kegiatan CSR sudah berkembang dan diterapkan oleh perusahaan dimasing masing sektor. Ada perusahaan yang sangat antusias menerapkan kegiatan CSR dan ada perusahaan yang masih setengah setengah dalam penerapan CSR itu sendiri. Indeks SRI-KEHATI dibentuk atas dasar keberlanjutan, dimana perusahaan perusahaan yang tergabung didalamnya telah lolos beberapa seleksi sehingga baik berkaitan dengan kinerja keuangan maupun kegiatan CSR. dengan demikian diketahui bahwa perusahaan dalam indeks SRI-KRHATI memiliki rasa pedulian dengan lingkungan sosial yang cukup tinggi dimana dibuktikan dengan kegiatan kegiatan CSR yang telah dilakukan.

Penelitian yang dilakukan Sutriani (2014) menyatakan bahwa perusahaan yang memiliki kinerja CSR yang tinggi menandakan juga bahwa perusahaan tersebut juga memiliki nilai rasio ROE yang tinggi. Penelitan yang dilakukan Rosdwianti (2016) juga menunjukan hasil bahwa CSR akan berpengaruh signigikan terhadap ROE. Berdasarkan paparan diatas maka hipotesis yang diajukan:

\section{H3: Terdapat perbedaan return on equity perusahaan yang masuk dalam indeks SRI- KEHATI dengan yang tidak masuk Indeks SRI-KEHATI.}

\section{Kinerja Pasar (price earnings ratio)}

Kinerja pasar adalah segala upaya yang dilakukan perusahaan untuk meningkatkan harga pasar saham perusahaan. Dalam penelitian ini kinerja pasar diproksikan menggunakan price earning ratio yang merupakan perbandingan antara per lembar saham dengan laba per lembar saham.

Seperti yang telah dijelaskan sebelumnya, perusahaan yang tergabung indeks SRIKEHATI adalah perusahaan yang memiliki bisnis inti yang ramah lingkungan dan tidak terlibat dalam bisnis yang bisa membahayakan kesehatan masyarakat seperti rokok, minuman keras dan perjudian. Perusahaan juga harus memiliki prospek keuangan yang baik. Dengan semua kualifikasi ini dapat diharapkan bahwa investor pasar modal memiliki kepercayaan yang kuat pada masa depan perusahaan sehingga mendorong mereka untuk berinvestasi pada saham perusahaan. Kepercayaan pasar terhadap perusahaan yang masuk dalam indeks SRIKEHATI akan mendorong kenaikan harga saham perusahaan sehingga price earnings ratio kelompok perusahaan yang masuk dalam indeks SRI-KEHATI diprediksi lebih tinggi daripada kelompok perusahaan yang tidak termasuk dalam indeks tersebut. Berdasarkan argumen tersebut maka hipotesis yang diajukan: 
H4: Terdapat perbedaan price earnings ratio kelompok perusahaan yang masuk indeks SRI-KEHATI dengan yang tidak masuk indeks SRI-KEHATI

\section{METODE PENELITIAN}

\section{Sampel Penelitian}

Populasi yang digunakan dalam penelitian ini adalah perusahaan perusahaan yang masuk dalam perhitungan indeks SRI-KEHATI. Dari populasi tersebut, sejumlah perusahaan diambil sebagai sampel dengan metode purposive sampling. Kriteria pengambilan sampel adalah: 1) Perusahaan yang masuk dalam indek SRI-KEHATI periode laporan keuangan tahun 2015 hingga 2017. 2) Menggunakan satuan mata uang rupiah dalam penyusunan laporan keungan. 3) Perusahaan yang digunakan sebagai kontrol sampel memiliki karakteristik yang sama. 4) Perusahaan berada dalam satu sub sektor yang memiliki lebih dari dua perusahaan.

Pada dasarnya penelitian ini adalah penelitian yang akan menguji perbedaan kinerja keuangan dengan kinerja pasar antara perusahaan dalam indeks SRI-KEHATI dengan perusahaan non indeks SRI-KEHATI sehingga perlu adanya kontrol sampel. Untuk menyeimbangkan perusahaan sampel dan kontrol sampel maka ada beberapa kriteria yang ditetapkan untuk kontrol sampel, yaitu:

1. Perusahaan dalam sub sektor yang sama dengan sampel penelitian.

2. Jumlah aset yang dimiliki perusahaan harus lebih dari 1 (satu) triliun rupiah.

3. Ukuran perusahaan sama atau relatif lebih tinggi dengan perusahan sampel.

4. Laporan keuangan menggunakan satua mata uang rupiah.

Berdasarkan kriteria yang telah ditetapkan, sebanyak 603 perusahaan dapat digunakan untuk pengujian hipotesis. Dari jumlah tersebut, sebanyak 317 observasi harus dihilangkan untuk memenuhi asumsi normalitas. Penormalan data dilakukan dengan membuang data-data yang memiliki nilai ekstrim. Sampel akhir yang tersedia berjumlah 286 observasi.

\section{Definisi dan Pengukuran Variabel}

\section{Net Profit Margin (NPM)}

Rasio ini merupakan perbandingan antara laba bersih yang dihasilkan dan penjualan. Formulanya adalah sebagai berikut:

$$
\text { Net Profit Margin }(\mathrm{NPM})=\frac{\text { Laba Penjualan }}{\text { Penjualan }}
$$

\section{Return on Asset (ROA)}

Rasio ini merupakan perbandingan antara laba bersih perusahaan dengan total aset yang dimiliki oleh perusahaan. Formulanya adalah sebagai berikut:

$$
\text { Return on asset }(\mathrm{ROA})=\frac{\text { Laba Bersih }}{\text { Total Aset }}
$$




\section{Return on Equity (ROE)}

Rasio ini merupakan tingkat pengembalian yang diperoleh pemilik bisnis atas modal yang telah ditanamkan. Formulanya adalah sebagai berikut:

$$
\text { Return on equity }(\mathrm{ROE})=\frac{\text { Laba Bersih }}{T \text { otal Ekuitas }}
$$

\section{Kinerja Pasar (PER)}

Rasio ini merupakan perbandingan antara harga saham dengan laba per lembar saham yang dimiliki oleh perusahaan. Formulanya adalah sebagai berikut:

$$
\text { Price Earning Ratio }(\mathrm{PER})=\frac{\text { Harga pasar per lembar saham }}{\text { Laba per Lembar Saham }}
$$

\section{HASIL DAN PEMBAHASAN}

\section{Pengelompokan Perusahaan}

Penilaian terhadap perusahaan yang masuk dalam indeks SRI-KEHATI dilakukan setiap enam bulan sekali yaitu bulan Mei dan November. Pada penelitian ini yang menjadi dasar data sampel adalah periode Mei-September pada tahun 2015 hingga 2017. Perusahaan dalam indeks SRI-KEHATI berjumlah 25 perusahaan yang mewakili sembilan sektor. Tahap awal pengelompokan perusahaan ini dilakukan dengan cara menyeleksi perusahaan yang menjadi anggota berturut-turut selama tahun penelitian dan menyajikan data keuangan yang dibutuhkan. Hasil dari penyeleksian tahap awal didapatkan data bahwa hanya terdapat 20 perusahaan yang menjadi anggota indeks SRI-KEHATI selama tahun 2015 hingga 2016. Langkah selanjutnya adalah menentukan kontrol sampel perusahaan yang berada dalam satu sub sektor yang sama. Jumlah kontrol sampel dari 9 sektor usaha tersebut menghasilkan data 413 perusahaan. Namun sebagian harus dikeluarkan untuk memenuhi asumsi normalitas data. Sampel akhir yang tersedia sebanyak 286 perusahaan yang terbagi dalam beberapa sektor: sektor pertanian sebanyak 3 perusahaan, sektor aneka industri sebanyak 4 perusahaan, sektor property, real estate dan konstruksi sebanyak 50 perusahaan, sektor keuangan sebanyak 218 perusahaaan dan sektor perdagangan, jasa dan investasi sebanyak 11 perusahaan.

\section{Statistik Diskriptif}

Tabel 1 menyajikan statistik deskriptif variabel-variabel penelitian. Nilai NPM pada perusahaan indeks SRI-KEHATI memiliki nilai minimum sebesar 0,10 dan nilai maksimum sebesar 0,50 sedangkan rata rata besarnya nilai NPM pada perusahaan indeks SRI-KEHATI memiliki nilai 0,26 dengan standart deviasi sebesar 0,13. NPM adalah kemampuan perusahaan dalam menghasilkan laba dari total penjualan yang ada dalam perusahaan tersebut. Dengan demikian dapat disimpulkan bahwa rata rata perusahaan yang masuk dalam kategori indeks SRI-KEHATI memiliki laba sebesar 26\% dari total penjualan. Sedangkan NPM pada perusahaan non indeks SRI-KEHATI memiliki nilai minimun sebesar 0,03 dan nilai maksimum sebesar 0,41 dengan rata rata 0,12 dan standar deviasi 0,08. Dapat disimpulkan rata rata perusahaan yang tidak masuk dalam kategori indeks SRI-KEHATI memiliki laba sebesar $12 \%$ dari total penjualan yang dimiliki. Dapat dilihat pada tabel 1 bahwa rata rata nilai NPM pada perusahaaan indeks SRI-KEHATI lebih tinggi dari pada rata rata nilai NPM pada perusahaan non indeks SRI-KEHATI. 
Tabel 1. Hasil Analisis Diskriptif Statistik

\begin{tabular}{|c|c|c|c|c|c|c|c|c|}
\hline \multirow{2}{*}{} & \multicolumn{4}{|c|}{ INDEKS SRI-KEHATI } & \multicolumn{3}{c|}{ NON INDEKS SRI-KEHATI } \\
\cline { 2 - 9 } & Minimum & Maksimum & $\begin{array}{c}\text { Rata- } \\
\text { Rata }\end{array}$ & $\begin{array}{c}\text { Deviasi. } \\
\text { Standar }\end{array}$ & Minimum & Maksimum & $\begin{array}{c}\text { Rata- } \\
\text { Rata }\end{array}$ \\
$\begin{array}{c}\text { Deviasi. } \\
\text { Standar }\end{array}$ \\
\hline NPM & 0.10 & 0.50 & 0.26 & 0.13 & 0.03 & 0.41 & 0.12 & 0.08 \\
\hline ROA & 0.01 & 0.22 & 0.08 & 0.07 & 0.00 & 0.10 & 0.02 & 0.02 \\
\hline ROE & 0.10 & 0.18 & 0.15 & 0.03 & 0.02 & 0.15 & 0.08 & 0.04 \\
\hline PER & 6.33 & 22.10 & 14.63 & 5.40 & 5.45 & 107.1 & 22.97 & 18.91 \\
\hline
\end{tabular}

ROA perusahaan indeks SRI-KEHATI memiliki nilai minimum sebesar 0,01 dan nilai maksimum 0,22 sedangkan rata rata ROA dalam indeks SRI-KEHATI sebesar 0,08 dengan standar deviasinya sebesar 0,07. ROA merupakan indikator berapa besar laba yang dapat dihasilkan oleh perusahaan dari total aset yang dimiliki, dengan demikian dapat disimpulkan bahwa rata-rata perusahaan dalam kelompok indeks SRI-KEHATI memiliki kemampuan menghasilkan laba 7\% dari total aset yang dimiliki.

Dari tabel 1 nilai ROA untuk perusahaan non indeks SRI-KEHATI memiliki nilai minimal sebesar 0,00 dan nilai maksimal sebesar 0,10. Rata-rata untuk perusahaan non indeks SRI-KEHATI memiliki laba sebesar $2 \%$ dari total aset yang ada dalam perusahaan tersebut. Nilai rata-rata ROA pada perusahaan non indeks SRI-KEHATI menunjukan nilai yang lebih rendah dari pada perusahaan indeks SRI-KEHATI.

Dari tabel 1 dapat diketahui bahwa ROE dalam perusahaan indeks SRI-KEHATI memiliki nilai minimal sebesar 0,10 dan nilai maksimum 0,18 . Rata-rata nilai ROE perusahaan dalam indeks SRI-KEHATI sebesar 0,15. Dengan kata lain rata-rata perusahaan dalam kelompok indeks SRI-KEHATI memiliki laba sebesar $15 \%$ kali dari total ekuitas yang dimiliki. Sedangkan ROE pada perusahaan non indeks SRI-KEHATI memiliki nilai minimal 0,02 dan nilai maksimal sebesar 0,15 sedangkan rata rata ROE pada perusahaan non indeks SRI-KEHATI memiliki nilai sebesar 0,08. Kesimpulan yang dapat ditarik bahwa rata rata perusahaan indeks SRI-KEHATI dalam penelitian ini yang tidak masuk dalam indeks SRIKEHATI memiliki laba sebesar $8 \%$ dari total ekuitas pada perusahaan tersebut.

PER adalah perbandingan antara harga saham perusahaan dengan laba per lembar saham. Dari tabel 1 nilai minimum PER pada perusahaan kelompok indeks SRI-KEHATI sebesar 6,33 dan nilai maksimum 22,10. Rata rata nlai PER dari kelompok indeks SRIKEHATI ini sebesar 14.63 yang artinya rata-rata harga saham dari kelompok indeks SRIKEHATI ini sebesar 14.63 kali laba per lembar saham yang dimiliki.

Dari tabel 1 menunjukan juga nilai PER pada perusahaan non indeks SRI-KEHATI dimana nilai minimum sebesar 5,45 dan nilai tertinggi sebesar 107,11 dengan rata-rata sebesar 22,97. Hal ini menunjukan bahwa rata rata harga saham pada perusahaan non indeks SRIKEHATI sejumlah 22,97 kali dari laba per lembar saham di perusahaan tersebut. Standar deviasi untuk kelompok ini 18,91 sehingga variabilitas datanya sangat inggi. 


\section{Pengujian Hipotesis}

Tabel 2 menunjukan bahwa nilai Sig(2-tailed) pada NPM bernilai 0,017 nilai tersebut lebih kecil dari pada nilai signifikan yang ditetapkan yaitu 5\%. Hal ini menunjukan bahwa hipotesis yang diajukan diterima yaitu terdapat perbedaan nilai NPM kelompok perusahaan yang masuk kedalam kategori indeks SRI-KEHATI dengan perusahaan non indeks SRIKEHATI. Salah satu penilaian yang dilakukan adalah dari aspek keuangan perusahaan dimana perusahaan yang masuk dalam kategori indeks SRI-KEHATI adalah perusahaan yang memiliki nilai PER positif. Secara tidak langsug nilai PER menggambarkan laba perusahaan. ketika perusahaan memiliki nilai PER yang positif maka laba perusahaan pastinya juga akan positif. Hal ini dapat disimpulkan bahwa perusahaan dalam indeks SRI-KEHATI memiliki kinerja laba yang baik. Ketika kemampuan perusahaan menghasilkan laba yang baik, maka akan berdampak pada rasio NPM, dimana rasio NPM ini merupakan gambaran dari kinerja laba perusahaan. Hasil penelitian ini memperkuat hasil-hasil riset tentang pengaruh CSR terhadap kinerja (Sitorus dan Mangoting, 2014).

Nilai Sig(2-tailed) yang dimiliki oleh ROA menunjukan hasil 0,033 Nilai tersebut kurang dari nilai signifikansi yaitu 5\% dengan demikian maka hipotesis yang diajukan diterima, bahwa terdapat perbedaan ROA antara perusahaan dalam indeks SRI-KEHATI dengan perusahaan non indeks SRI-KEHATI. Terdapat tiga kriteria finansial yang disyaratkan untuk perusahaan perusahaan yang masuk dalam indeks SRI-KEHATI. dimana salah satu syarat tersebut adalah perusahaan yang masuk dalam indeks SRI-KEHATI adalah perusahaan perusahaan yang memiliki nilai aset lebih dari satu triliun. ROA adalah indikator seberapa besar laba yang dapat dihasilkan oleh perusahaan dari total aset yang dimiliki. Ketika perusahaan memiliki laba yang tinggi, maka peluang perusahaan untuk memanfaatkan aset aset yang dimiliki juga lebih tinggi. Perusahaan kelompok indeks SRI KEHATI tentunya selain memiliki nilai aset yang tinggi juga memliki kepedulian pada lingkungan sekitar. Hasil ini sesuai dengan penelitian sebelumnya bahwa perusahaan yang melakukan kegiatan CSR dapat meningkatkan kinerja rasio profitabilitasnya (Rosdwianti, 2016).

Tabel 2. Uji Beda Rasio Keuangan dan Pasar

\begin{tabular}{|c|c|c|c|c|}
\hline & & $\begin{array}{l}\text { Levene } \\
\text { Equality }\end{array}$ & $\begin{array}{l}\text { est for } \\
\text { ariances }\end{array}$ & $\begin{array}{l}\text { t-test for } \\
\text { Equality of } \\
\text { Means }\end{array}$ \\
\hline & & $\mathrm{F}$ & Sig. & Sig. (2-tailed) \\
\hline NPM & $\begin{array}{l}\text { Equal variances assumed } \\
\text { Equal variances not } \\
\text { assumed }\end{array}$ & 8.159 & .005 & $\begin{array}{l}.000 \\
.017\end{array}$ \\
\hline ROA & $\begin{array}{l}\text { Equal variances assumed } \\
\text { Equal variances not } \\
\text { assumed }\end{array}$ & 46.284 & .000 & $\begin{array}{l}.000 \\
.033\end{array}$ \\
\hline
\end{tabular}




\begin{tabular}{|ll|r|r|r|}
\hline ROE $\quad \begin{array}{l}\text { Equal variances assumed } \\
\text { Equal variances not } \\
\text { assumed }\end{array}$ & .608 & .436 & .000 \\
\hline PER $\quad \begin{array}{l}\text { Equal variances assumed } \\
\text { Equal variances not } \\
\text { assumed }\end{array}$ & 4.051 & .045 & .000 \\
\hline
\end{tabular}

Sumber : Data sekunder yang telah diolah (2019)

Hasil tabel analisis statistik menunjukan bahwa nilai Sig (2-tailed) pada ROE menunjukan angka 0,000. Nilai tersebut menjelaskan bahwa hipotesis yang diajukan dalam penelitian ini diterima, yaitu nilai ROE yang dimiliki oleh perusahaan dalam indeks SRIKEHATI berbeda dengan nilai ROE yang dimiliki perusahaan non indeks SRI-KEHATI. ROE adalah cerminan seberapa besar laba yang dimiliki perusahaan dari total ekuitasnya. Proksi ROE hampir memiliki kriteria yang sama dengan proksi ROA. Ketika perusahaan mampu menghasilkan laba yang tinggi, maka akan berdampak pula pada besarnya nilai rasio ROE. Melihat tabel 1 didapatkan data bahwa rata rata perusahaan dalam kategori indeks SRIKEHATI memiliki rata rata ROE 0,1520 dimana rata rata tersebut lebih tinggi dari pada perusahaan non indeks SRI-KEHATI yang memiliki rata rata sebesar 0,0746. Salah satu penyebab unggulnya nilai rata rata dari perusahaan indeks SRI-KEHATI adalah perusahaan dalam indeks SRI-KEHATI memiliki kinerja laba yang tinggi sehingga akan memunculkan peluang perusahaan untuk menghasilkan laba yang besar dari total ekuitas yang dimiliki. Penelitian ini memperkuat hasil-hasil sebelumnya seperti Sutriani (2014) dan (Rosdwianti, 2016).

Dari tabel 2 dapat diketahui bahwa nilai Sig(2-tailed) pada PER memiliki nilai 0,001 dengan kata lain nilai tersebut lebih rendah dari nilai signifikan yaitu 0,05 yang artinya bahwa hipotesis yang diajukan diterima. Perusahaan dalam indeks SRI-KEHATI memiliki salah satu kriteria penilaian yaitu perusahaan yang memiliki nilai PER positif dan saham publik lebih dari $10 \%$. Hal ini menunjukan bahwa perusahaan dalam indeks SRI-KEHATI memiliki tingkat kepercayaan dimata masyarakat. Selain itu masyarakat juga lebih memilih perusahaan yang berkelanjutan dan kepedulian sosial yang tinggi terhadap lingkungan sekitar. Kedua hal tersebut juga merupakan tujuan dari dibentuknya indeks SRI-KEHATI. sehingga pastinya perusahaan yang masuk dalam kategori indeks SRI-KEHATI memiliki kedua kriteria tersebut sehingga masyarakat tertarik dalam menanamkan dana yang dimiliki. Hasil penelitian ini memperkuat pendapat Lako $(2015 ; 124)$ investor atau pelaku pasar akan lebih mengapresiasi perusahaan perusahaan yang memiliki kinerja CSR yang tinggi daripada perusahaan yang kurang peduli atau bahkan tidak melakukan kegiatan CSR itu sendiri.

\section{SIMPULAN}

Berdasarkan hasil uji statistik yang telah dilakukan maka dapat ditarik kesimpulan bahwa terdapat perbedaan Net Profit Margin, Return On Asset, Return on Equity dan Price Earning Ratio antara perusahaan yang masuk dalam kelompok indeks SRI-KEHATI dengan 
perusahaan non indeks SRI-KEHATI. Saran yang diberikan untuk penelitian selanjutnya adalah penelitian selanjutnya diharapkan menambah variabel lain misalnya tata kelola perusahaan yang dapat diproksikan dengan kepemilikan manajerial, kepemilikan institusional, dan lain lain, variabel ini dapat dipilih karena salah satu syarat perusahaan yang masuk dalam indeks SRI-KEHATI adalah perusahaan perusahaan yang memiliki kinerja yang baik dan tata kelola yang baik pula sehingga peneliti selanjutnya dapat meneliti apakah memang terdapat perbedaan dalam sisi tata kelola perusahaan antara perusahaan yang masuk dalam kelompok indeks SRI-KEHATI dengan perusahaan non indeks SRI-KEHATI.

\section{DAFTAR PUSTAKA}

Agnes.S, 2009. Analisa Kinerja Keuangan dan Perencanaan keauangan Perusahaan, Jakarta: PT. Gramedia Pustaka Utama.

Alexander, N., dan N. Destriana. 2013. Pengaruh Kinerja Keuangan Terhadap Return Saham, Jurnal Bisnis Akuntansi;15(2), 123-132. Diunduh dari: https://jurnaltsm.id/index.php/JBA/article/view/124/124

Fahmi, I. 2013. Manajemen Investasi. Edisi. Kedua. Jakarta; Salemba Empat.

Halim, A dan M. Mamduh. 2009. Analisis Laporan Keuangan. Edisi. Keempat. Yogyakarta: UPP STIM YKPN.

Hantono. 2018. Konsep Analisis Laporan Keuangan Dengan Pendekatan Rasio dan SPSS, Yogyakarta: CV Budi Utama.

Hartono, J. 2016. Teori Portofolio dan Analisis Investasi. Edisi. Sebelas. Yogyakarta: BPFE.

Kurniasari, W dan Y. Warastuti. 2015. The Relationship Between CSR and Profitability to Firm Value in SRI-KEHATI Index. The International Journal of Economic Behavior, 5 (1): 31-41.

Lindarwati, F. dan T. Budianto. 2008. Pengaruh Corporate Social Responsibility Terhadap Kinerja Keuangan Perusahaan yang Terdaftar Sebagai 100 Best Corporate Citizens oleh KLD Research \& Analytics. Majalah Ekonomi Th XVIII No 1, hlm 66-83. Diunduh dari: https://e-journal.unair.ac.id/JEBA/article/view/4236/2876

Keputusan Direksi PT Bursa Efek Jakarta Nomor: Kep-306/BEJ/07-2004. Diunduh dari: https://www.idx.co.id/Portals/0/StaticData/Regulation/ListingRegulation/id-

ID/Peraturan_I-E_Gabung.pdf dan (https://crmsindonesia.org/mengenal-indekskeberlanjutan-perusahaan-dari-sri-kehati/).

Sutriani, A. 2014. Pengaruh Profitabilitas, Leverage, dan Likuiditas Terhadap Return Saham dengan Nilai Tukar sebagai Variabel Moderasi pada Saham LQ-45. Jurnal Bisnis Dan Banking, 4(1), 67-80.

Rosdwianti, M. K, Moch. Dzulkirom, dan Z. A. Zahroh. 2016. Pengaruh Corporate Social Responsibility (CSR) Terhadap Profitabilitas Perusahaan (Studi Pada Sektor Industri Barang Konsumsi Yang Terdaftar Di Bursa Efek Indonesia Periode 2013-2014). Jurnal Administrasi Bisnis, 38 (2). 
Jurnal Akuntansi Bisnis, Vol. 18, No. 2, September 2020

ISSN 1412-775X (media cetak) | 2541-5204 (media online)

Sitorus, C. T. dan Y. Mangoting. 2014. Pengaruh Pengungkapan Corporate Social Responsibility Terhadap Profit Perusahaan Consumer Goods Di Indonesia Tahun 2010 - 2012. Tax \& Accounting Review Vol 4 No 1. Diunduh dari: https://www.neliti.com/id/publications/157255/pengaruh-pengungkapan-corporatesocial-responsibility-terhadap-profit-perusahaan.

Yayasan Keanekaragaman Hayati; Jakarta. Diunduh dari: dari www.kehati.org.id

Yaparto, M., D. Frisko, dan R. Eriandani. 2013. Pengaruh Corporate Social Responsibility Terhadap Kinerja Keuangan Pada Sektor Manufaktur Yang Terdaftar Di Bursa Efek Indonesia Pada Periode 2010-2011, 2(1), 1-19. Diunduh dari: http://journal.ubaya.ac.id/index.php/jimus/article/view/106/84 